\title{
Social Media as a Development Tool English Communicative Competence
}

\author{
Vasyl Puzanov ${ }^{1, *}$, Galyna Volynets ${ }^{2}$, Olha Lesiuk $^{3}$, Daria Kharamurza ${ }^{4}$, Kateryna Vashyst $^{5} \&$ Maryna Sadivnycha $^{6}$ \\ ${ }^{1}$ Department of Theory and Practice of Translation (English), Zaporizhzhia National University, Zaporizhzhia, \\ Ukraine \\ ${ }^{2}$ Department of Journalism, National University “Zaporizhzhia Polytechnic”, Zaporizhzhia, Ukraine \\ ${ }^{3}$ Department of Journalism, University of Customs and Finance, Dnipro, Ukraine \\ ${ }^{4}$ Department of Advertising and Public Relations, Institute of Journalism, Borys Grinchenko Kyiv University, Kyiv, \\ Ukraine \\ ${ }^{5}$ Foreign Languages Department, Sumy State University, Sumy, Ukraine \\ ${ }^{6}$ Department of Journalism and Philology, Sumy State University, Sumy, Ukraine \\ *Correspondence: Department of Theory and Practice of Translation (English), Zaporizhzhia National University, 66 \\ Zhukovsky Street, 69600, Zaporizhzhia, Ukraine
}

Received: December 7, 2021

Accepted: January 6, 2022 Online Published: January 17, 2022

doi:10.5430/jct.v11n1p101

URL: https://doi.org/10.5430/jct.v11n1p101

\begin{abstract}
The purpose of the research is to determine the effectiveness of the practical application of social media based on Web 2.0 technologies, aimed at developing students' English-speaking communicative competence. To implement the tasks and test the hypothesis put forward, the following scientific research methods were used: empirical (experimental learning using social media based on Web 2.0); diagnostic: observation, testing of students; statistical method - mathematical analysis of the data obtained during the experiment; descriptive: description and verbal recording of results. The results of the experimental study showed the correctness of the hypothesis put forward that the formation of English-speaking communicative competence among students will become more effective when creating a methodology using social media formed on technologies Web 2.0. For practical implementation of obtained theoretical conclusions after the experiment, it is necessary to have certain pedagogical conditions. Among these: taking into account the peculiarities of the educational environment, enhancing the speech activity of students with the participation of social media based on Web 2.0 technologies. They were developed on the basis of the results of diagnostics of the level of formation of the English-speaking communicative competence in the process of teaching students in streaming mode. Future scientific searches are possible in the direction of theoretical substantiation and practical application of new social media based on Web 2.0 technology in other training courses and other (non-philological) specialties. This vector of research is especially necessary during distance learning as an alternative to the traditional educational process.
\end{abstract}

Keywords: foreign language competence, educational Internet resources, Web 2.0 technologies, experiment, social media

\section{Introduction}

Relevance. Modern trends in the sphere of education dictate the need to use new sources in teaching foreign languages, in particular, to increase communicative competence (Bondar et al., 2021; Trinder, 2017). This is primarily due to the spread of the Bologna education system in the world and the very rapid development of the Internet computer network, especially as a result of the coronavirus pandemic (Prokopenko et al., 2020). As classroom technology and online courses become more prevalent, educators and students have new ways of teaching, planning classes and presenting information ( $\mathrm{Li}$ et al., 2020). Internet activities are often practical and interactive, so students get the opportunity to directly engage in organizing information, and not just passively listen to lectures (Gumenyuk et al., 2021; Popovych et al., 2020). 
Web 2.0 technologies open new opportunities for the educational process, in particular for mastering the English language. The use of computer technology during the lesson and in extracurricular activities opens up new ways of presenting information, gives impetus to the implementation of own projects. Well-known blogs, podcasting, media objects, wikis, social bookmarks are the most popular social services of the Web 2.0 network, which can be used effectively in the study of English, including the development of communicative competence (Akkara, Anumula \& Mallampalli, 2020; Dizon, 2021).

The purpose of the article is to determine the effectiveness and practical application of the system of Internet resources in education formed on Web 2.0 technologies, aimed at developing students' English-speaking communicative competence.

According to the purpose of the study, it is necessary to solve the following tasks:

- based on the analysis of the structure of foreign language communicative competence, to develop the author's model of the formation of foreign language communicative competence through the use of educational Internet resources based on Web 2.0 technologies for 2-3 year students of the Faculty of Foreign Languages within the framework of the discipline "Practical English language course";

- analyze training scientific materials in Internet formed on technologies Web 2.0;

- to develop a system of exercises for study with scientific materials in Internet formed on technologies Web 2.0 for

2-3 courses, aimed at the formation of the corresponding components of a foreign language communicative

competence;

- experimentally to check how effective the process of the formation of English competence of communication among 2-3 year students of the Faculty of Foreign Languages at a pedagogical university will be effective due to the use of a system of exercises for study with scientific materials in Internet formed on technologies Web 2.0.

\section{Literature Review}

The question of researching the use of social media to improve English-speaking communicative competence is considered in several aspects. In particular, scientists pay attention to such positive characteristics as accessibility, mobility, ease of use, privacy, practicality, dynamism, etc. (Godwin-Jones, 2018, 2019; Huzairin, Putrawan \& Riadi, 2020).

However, in the scientific discourse, topical issues of theoretical justification and practical application of social media based on Web 2.0 technology still remain uncovered. A characteristic feature of Web 2.0 technology compared to first-generation technologies is the ability of Web 2.0 not only to observe web resources of the Internet, but also to add their own, share with other users, act according to purpose (in our case - development of English communicative competence), discuss and etc. Therefore, the main thing here is the individual with his interests, needs, ideas for implementation, valuable experience. Given this, educational technologies Web 2.0 act as intermediaries in the information field of the network. The experience of foreign countries in the use of social networking sites for the development of informal communication in universities in this aspect is convincing: in Malaysia (Ismail \& Shafie 2019), Denmark (Jensen, 2017), Spain (Vazquez-Calvo, 2020), Slovenia (Jurkovič, 2018), UK (Baratta, 2017); Indonesia (Putrawan \& Riadi, 2020), Arab countries (Qadha, Al-Wasy \& Mahdi, 2021; Rababah, 2020; Rahimah, 2018).

An important aspect in learning English, in particular communicative competence, is the ability to communicate effectively. Such factors, are the key factors influencing the quality of communication in the study of spoken English skills (Bessarab et al., 2021; Leong \& Ahmadi, 2017; Poplavskyi, Rybinska \& Ponochovna-Rysak, 2020). Various interactive exercises, numerically presented in social media, develop speech abilities, perform an important function related to the stimulation of speech utterances. According to Lee and Drajati (2019), high-quality teaching of speech activity is impossible without interactivity. Especially popular for such purposes among students is the use of social networks Facebook, Instagram, TikTok (Mykytiuk, Lysytska \& Melnikova, 2020; Pooley, Midgley \& Farley, 2019) Their positive impact is significant, as scientists rightly point out. However, the question of the practical application of social media based on Web 2.0 technologies remains out of attention. 


\section{Methods and Materials}

\subsection{Research Procedure}

The experiment was carried out at the Faculty of Foreign Languages of the Ivan Franko Lviv National University with 2-3-year full-time students of the specialty "English Language and Literature" (translation). 2nd year students (2 subgroups) and 3 courses ( 2 subgroups) participated in the experiment during the 2018-2020 academic years.

The training experiment included the following steps:

1.pre-experimental slice;

2. an actual teaching experience;

3. intermediate cut;

4. questionnaire survey;

\section{Post-experimental section.}

Research hypothesis: the process of developing English-speaking communicative competence among 2-3 year students of the Faculty of Foreign Languages within the framework of the discipline "Practical English Course" will become more effective if a method of study with scientific materials in Internet formed on technologies Web 2.0 is created. It provides for a system of exercises aimed at the formation of all components of the English-speaking communicative competence of 2-3 year students within the framework of the "Practical English course" discipline.

\subsection{Sampling}

The first stage involved identifying the initial level of formation of foreign language communicative competence among students in order to determine the quantitative and qualitative composition of the "sample population" of students, which is sufficient for testing after experimental training. In addition, the experimental groups should be compared with each other at different points and stages of the study. Consequently, monitoring is carried out on two groups of students for two years. To obtain more statistically reliable results, it is recommended to select correlated pairs of students who have extremely close indicators for a given criterion. This will allow taking into account not the averaged data, but for each individually. To determine the initial level of formation of foreign language communicative competence among 2 nd year students and the possibility of using them, it is necessary to conduct a pre-experimental section.

The experiment was carried out in the 2018-2020 academic years in two groups of 10-11 people each. The tasks of the Certificate of the 6th Level of General Proficiency, done in Cambridge, and posted in the public domain at https://www.flo-joe.co.uk/cae/students/tests/. Based on the test results, a sample of students was formed for the experiment under study. In addition, an additional survey was conducted in the form of a closed questionnaire in order to study the practical use of Internet facilities formed on technologies Web 2.0 (Appendix A). Subsequently, using the same objectives of the Level 6 Certificate in General Language Proficiency in Cambridge, established communication competencies were investigated using scientific materials in Internet formed on technologies Web 2.0 .In order to visualize the results obtained, it was decided to give the students fictitious names.

\subsection{Used Research Methods}

To implement the tasks and test of the hypothesis, scientific research methods were used:

- empirical: experimental learning using scientific materials in Internet formed on technologies Web 2.0 for the formation of foreign language communicative competence among 2-3 year students of the Faculty of Foreign Languages, studying in the specialty "Foreign Language (English and Literature, Translation)";

- diagnostic: observation, testing of students in the process of forming a foreign language communicative competence when using scientific Internet resources formed on Web 2.0, questioning students;

- statistical - mathematical study of the data obtained in the process of a pedagogical experiment;

- descriptive: description and verbal recording of the results obtained.

\section{Results}

The experiment carried out was:

- educational (since it was done through the learning process);

- test (since it served to practice future provisions); 
- horizontal (experimental groups);

- natural (the experiment was carried out in ordinary study groups developed at the beginning of studying);

- open (during the experiment, adjustments were made, the formulation of tasks was changed).

Having analyzed the answers of the pre-experimental section made it possible to conclude that students in the experimental groups have an average number of formation of English communicative competence. This suggests that students will improve the level of foreign language communicative competence through constantly study with scientific materials in Internet formed on technologies Web 2.0, including social media.

The second step of the research is the actual training experiment, when developed system of exercises for studying with training. Scientific materials in Internet formed on technologies Web 2.0 was tested for the formation of foreign language communicative competence in 2-3 year students of the Faculty of Foreign Languages. The training experiment was conducted during the 2018-2019 and 2019-2020 academic years. The duration of the training experiment is due to the fact that the preparation of training scientific materials in Internet formed on technologies Web 2.0 required a lot of time on the part of the teacher. In addition, the result of working with training scientific materials in Internet formed on technologies Web 2.0 is delayed in time. For these reasons, the educational experiment lasted 2 academic years, which made it possible to track the progress of students in both 2 and 3 courses.

Before presenting a detailed description of classes using training Internet resources based on Web 2.0 technologies, it should be noted that all training Internet resources correspond to the subject of the curriculum of Ivan Franko Lviv National University. Here are examples of training scientific materials in Internet formed on technologies Web 2.0 for the 2nd year (Appendix B).

It is necessary to dwell in more detail on the conditions for evaluating the Webquest educational format. The maximum you can score is 15 points, thus, "excellent" - more than 12 points - corresponds to a high level of English competence of communication of students; "Good" - from 11 to 9 points and "unsatisfactory" - 8 points or less corresponds to a low level of foreign language communicative competence formation among students of experimental groups (EG-1 and EG-2).

The number of points scored by students of groups EG-1 and EG-2 is presented in Table 1.

The maximum number of points was scored by 3 students, which amounted to $27 \%$ of the total number of students the indicator is quite high. In general, EG-1 coped with the task successfully, demonstrating a high and average level of formation of foreign language communicative competence within the discipline "Practical course of the English language". The training rate was $100 \%$.

In EG-2, two students scored the maximum number of points, which was $20 \%$ of the total number of students. EG-2 also successfully coped with the task, demonstrating high and medium levels of formation of foreign language communicative competence within the discipline "Practical English language course". The training rate was 100\%.

Since the training experiment covers a sufficiently long period of time, as a result of which the pre-experimental and post-experimental sections were significantly separated from each other in time. At the end of 2019-2020 u.y., another section was carried out on similar tasks on the site https://www.flo-joe.co.uk/cae/students/tests/, as in the previous task when choosing students for the experiment. There was additionally a survey in the form of an open questionnaire on the importance of using social media in the development of foreign language communicative competence. (Appendix A). The purpose of the current section was to identify the dynamics of the development of key competencies in students and to check the effectiveness of the proposed methodology for the formation of foreign language communicative competence in students through the use of scientific materials in Internet formed on technologies Web 2.0.

The cut consisted of 5 sections: reading (Reading - 1 hour 15 minutes), writing (Writing - 1.5 hours), application of the language (Use of English - 1 hour 30 minutes), listening (Listening - 45 minutes), speaking (Speaking - 15 minutes). Since the tasks of the test were quite laborious, the testing went through three stages. At the first stage, reading and writing skills were tested, at the second, language skills, speaking and listening skills, at the third stage, students conducted micro-lessons.

Thus, for all parts of the Cambridge exam, students can receive a maximum of 253 points. The identification of three stages of formation of English competence of communication occurs according to the following parameters: high level - 80\% -100\% - 201 points or more; average level - 60\% -79\% - 151-200 points; low level - less than $60 \%-150$ points or less. 
Table 1. The Number of Points Scored by Students When Completing the "Royal Wedding" Webquest in the 2nd Year

\begin{tabular}{|c|c|}
\hline Student's name & Number of points \\
\hline \multicolumn{2}{|l|}{ EG-1 } \\
\hline 1.Sofiya & 11 \\
\hline 2.Ksenya & 15 \\
\hline 3.Olya & 9 \\
\hline 4. Natalya & 9 \\
\hline 5.Kateryna & 10 \\
\hline 6. Oksana & 9 \\
\hline 7.Anton & 9 \\
\hline 8.Tetyana & 11 \\
\hline 9.Denys & 15 \\
\hline 10. Andrij & 11 \\
\hline 11.Svitlana & 15 \\
\hline \multicolumn{2}{|l|}{ EG-2 } \\
\hline 1. Maryna & 15 \\
\hline 2. Natalya & 11 \\
\hline 3.Olya & 10 \\
\hline 4.Polina & 15 \\
\hline 5.Vitalina & 9 \\
\hline 6.Valeriya & 12 \\
\hline 7.Matvij & 13 \\
\hline 8.Marco & 12 \\
\hline 9.Daryna & 11 \\
\hline 10.Kateryna & 11 \\
\hline
\end{tabular}

The dynamics of changes in the average number of points in the experimental group at the current cut, presented in Table 2.

The results of the current slice were compared with the results of the pre-experimental slice. The analysis of the results of the current section showed that when performing the tasks of the Certificate of the University of Cambridge, the average indicators changed in the studied groups. Analyzing the data of the current section, we can conclude that the results of responses from groups EG-1 and EG-2, whose training was based on the use of scientific social media formed on technologies Web 2.0, increased by an average of $8 \%-9.6 \%$ (180 - 183 points).

The results of the current section confirmed the initially put forward hypothesis that the process of forming an English competence of communication will become more effective if a special methodology for study with scientific materials in Internet formed on technologies Web 2.0 is created. This applies to students of 2-3 courses of the Faculty of Foreign Languages of a pedagogical university in the framework of the discipline "Practical Course of the English Language". This idea has a right to exist and deserves further consideration and testing in practice.Teaching a foreign language using scientific materials in Internet formed on technologies Web 2.0 continued in the same groups already in the $3 \mathrm{rd}$ year. Consider examples of training scientific materials in Internet formed on technologies Web 2.0 for the 3rd year (Appendix C). 
Table 2. The Level of Formation of Foreign Language Communicative Competence among 2nd Year Students According to the Result of the Current Cut

\begin{tabular}{ll}
\hline Student's name & Number of points \\
\hline EG-1 & 176 \\
1.Sofiya & 181 \\
2.Ksenya & 176 \\
3.Olya & 176 \\
4.Natalya & 177 \\
5.Kateryna & 160 \\
6. Oksana & 158 \\
7.Anton & 177 \\
8.Tetyana & 191 \\
9. Denis & 184 \\
10. Andrij & 196 \\
11.Svitlana & \\
EG-2 & 184 \\
1.Maryna & 185 \\
2.Natalya & 182 \\
3.Olya & 183 \\
4.Polina & 175 \\
5.Vitalina & 169 \\
6.Valeriya & 166 \\
7.Matvij & 189 \\
8.Marko & 177 \\
10.Karyna & 188 \\
\hline
\end{tabular}

In the course of teaching English to students in 2 and 3 courses, 50 scientific materials in Internet formed on technologies Web 2.0 were tested, aimed at the formation of all components of a foreign language communicative competence.

A post-experimental slice completed the learning experiment. Its purpose was to test the effectiveness of the developed system of scientific materials in Internet formed on technologies Web 2.0, aimed at developing students' foreign language communicative competence. The test items for the post-experimental section, as in the previous stages of the experiment, consisted of the item for the Level 6 Certificate of General Language Proficiency, done by Cambridge.

The results of the post-experimental section were reviewed and compared with the results of the pre-experimental section. The results of the post-experimental section of the experimental groups are presented in Table 3 . 
Table 3. The Level of Formation of Foreign Language Communicative Competence among 3rd Year Students According to the Results of the Post-Experimental Section

\begin{tabular}{ll}
\hline Student's name & Number of points \\
\hline EG-1 & 198 \\
1.Sofiya & 198 \\
2.Ksenya & 192 \\
3.Olya & 191 \\
4.Natalya & 195 \\
5.Kateryna & 174 \\
6.Oksana & 174 \\
7.Anton & 196 \\
8.Tetyana & 206 \\
9.Denys & 197 \\
10. Andrij & 232 \\
11.Svitlana & \\
EG-2 & 206 \\
1.Maryna & 205 \\
2.Natalya & 205 \\
3.Olya & 204 \\
4.Polina & 202 \\
5.Vitalina & 191 \\
6.Valeriya & 184 \\
7.Matvij & 209 \\
8.Marko & 201 \\
9.Daryna & 215 \\
10. Kateryna &
\end{tabular}

The middle point in EG-1 increased to 196 points (previous experiment - 167 points). The middle point in EG-2 increased to 202 points (previous experiment - 167 points). The difference between the results of the experimental groups is obvious.

After analyzing the data of the pre-experimental stage, it is obvious that in the experimental groups the students did not demonstrate a high level of formation of foreign language communicative competence. The results of the post-experimental section prove that in the experimental groups, students with a low level of formation of foreign language communicative competence improved their results and moved to the group with average indicators. At the same time, students with a high level of formation of foreign language communicative competence appeared in the experimental groups: in EG-1 their number is 2 people, that is, $18 \%$ of students, in EG-2 their number is 3 people, that is, $30 \%$.

These results confirm the correctness of the initially put forward hypothesis that the process of forming a foreign language communicative competence will become more effective if a method of study with scientific materials in Internet formed on technologies Web 2.0 is created. This characterizes the students of 2-3 courses of the Faculty of Foreign Languages of the Ivan Franko Lviv National University in the framework of the discipline "Practical Course of English". It clearly defines the range of skills and abilities of foreign language communicative competence of 2-3 year students and takes into account the features of Web 2.0 technologies. These features include: publicity, nonlinearity, the ability to make changes to the published material, interactivity, autonomy in the work and posting of material, the possibility of moderation, commenting, the ability to create a personal zone by each author. Also, the 
methodological conditions necessary for the successful formation of foreign language communicative competence of 2-3 year students are relevant. We are talking about the inclusion of a system of exercises aimed at the formation of all components of foreign language communicative competence among students of 2-3 courses within the discipline "Practical course of the English language".

Based on the results of the experiment, a questionnaire survey of 3rd year students was carried out to identify their attitude to the use of scientific materials in Internet formed on technologies Web 2.0 in practical classes in English (Appendix A). The survey showed that the students of the experimental groups consider the training scientific materials in Internet formed on technologies Web 2.0 to be an effective means of forming a foreign language communicative competence, since the training Internet resources stimulate speech activity. However, $27 \%$ of respondents emphasized that not all formats of educational Internet resources can be used at the initial stages of language learning. These include such task formats as Inside Reflector, Subject Sample and Webquest. These formats, according to students, are more suitable for advanced stages of study. $90 \%$ of 3 rd year students scientific materials in Internet formed on technologies Web 2.0 interesting and are going to use them in their future professional activities. Students prefer to complete assignments in pairs or groups, which indicates a desire to interact with each other.

The most popular formats are those that provide for the expression of one's own opinion: discussions, solving personal problems, project work, role-playing games, tasks of overcoming information imbalance. All these tasks are aimed at improving the skills of unprepared oral monologue and dialogical speech. Less interest is aroused scientific materials in Internet formed on technologies Web 2.0 (Inside Reflector), which are associated with the formation and improvement of the written language skills. This is probably due to the greater laboriousness of such tasks and the insufficient degree of formation of skills and abilities, therefore, it is necessary to continue their active use so that the implementation ceases to be difficult.

\section{Discussion}

The results of the experimental work confirmed the correctness of the hypothesis put forward that the formation of foreign language communicative competence among students of 2-3 courses will become more effective under certain conditions. This will become possible if a special methodology for study with scientific materials in Internet formed on technologies Web 2.0 is created.

The model of development of English competence of communication described in this study in 2-3 year students studying in the specialty "Foreign language (English and literature, translation)" through the study with scientific materials in Internet formed on technologies Web 2.0, meets the tasks set in the study. It can be concluded that the experiment demonstrated compliance with the purpose and objectives of the study.

The formation and development of English-speaking communicative competence among 2-3 year students of the Faculty of Foreign Languages is based on the methodology of study with scientific social networks formed on technologies Web 2.0. The methodology is based on the principles of formation of basic communicative competencies in students, criteria for selecting the content of training, a system of exercises for study with scientific materials in Internet formed on technologies Web 2.0. Control and measuring materials are also important for determining the level of formation of the English-speaking communicative competence among students. Such criteria fully meet the current requirements of education and training (Kiki-Papadakis \& Chaimala, 2016; Zhernova, 2018) and contribute to the development of the information culture of humanities students in general (Reaser, 2016; Synorub \& Medynska, 2019).

The effectiveness of the use of digital online technologies is obvious for teaching informal English not only to philology students (as in the study), but also to those wishing from technical or natural specialties (Yurieva, Musiichuk \& Baisan, 2021). It is a practical application, according to Wang (2017), that cloud computing technologies, which, in combination with social media, open up wide opportunities for learning English, in particular, improving writing skills. The mobility of using these social media or other applications for learning English is discussed in the «Phone or Hostel» study (Şad et al., 2020). Other scientists, in particular Lee and Dressman (2017) and Lee (2020) quite rightly emphasize the convenience in everyday use of smartphones loaded with educational social media, file sharing, instant messengers, mobile applications (Khaleel, Wook \& Ashaari, 2018). However, along with the obvious advantages, there are significant imperfections of such a method of learning a foreign language, in particular on the part of the teacher, who sometimes finds it difficult to effectively maintain sufficient communication with all students on social networks (Rababah, 2020), in particular on Facebook (Purnamasari, 2019) or Instagram (Gonulal, 2019). 
The limitation is that it takes a lot of time (one or two academic years) to effectively conduct it and analyze the data for continuous and effective monitoring of educational goals. It is also worth taking a long time to find appropriate Web 2.0-based Internet resources for each lesson.

The practical use of the obtained experimental results is possible in the educational process in universities at the faculties of foreign languages, not only for the development of foreign language communicative competence in English, but also with appropriate changes for other languages. The results obtained will become a logical addition to the methodology for the development of foreign language communicative competence, contribute to the deepening of research in linguistics and translation studies. The main provisions of the experiment carried out can be applied not only in the practice of teaching a practical course of the English language, but also in the correspondence department, in refresher courses, in the compilation of textbooks and teaching aids. This technique is effective in self-education.

Future scientific research is possible in the direction of theoretical substantiation and practical use of scientific materials in Internet formed on technologies Web 2.0, which are being actively updated. This vector of research is especially necessary during distance learning as an effective alternative to the traditional educational process. The experiment carried out does not exhaust all the questions concerning the process of forming students' English-speaking communicative competence through the use of social media formed on technologies Web 2.0. Prospects for future study can be associated with the expansion of the system of scientific materials in Internet formed on technologies Web 2.0, deepening the formation and experimental testing of other educational social media formed on technologies Web 2.0 in other courses.

\section{Conclusions}

The relevance of this study lies in the development of a methodology for study with scientific materials in Internet formed on technologies Web 2.0, which is aimed at developing students' English competence of communication, easily and organically fits into the general context of teaching a foreign language in universities.

The practical application of the methodology and the results of the experiment under study finds its solution in using them in the educational process in universities at the faculties of foreign languages not only for English, but with a corresponding transformation for other languages. The results obtained will become a logical addition to the methodology for the development of foreign language communicative competence.

Future scientific searches are possible in the direction of expanding and deepening the already obtained results by using new Internet resources based on Web 2.0 technology, which are increasingly updated and supplemented. This line of research is especially needed during the coronavirus pandemic as an effective alternative to the impossibility of conducting traditional classroom activities.

\section{References}

Akkara, S., Anumula V. S. S., \& Mallampalli, M. S. (2020). Impact of Whats App interaction on improving 12 speaking skills. International Journal of Emerging Technologies in Learning (iJET), 15(03), 250-259. https://doi.org/10.3991/ijet.v15i03.11534

Baratta, A. (2017). Accent and linguistic prejudice within British teaching. Journal of Language, Identity and Education, 16(6), 416-423. https://doi.org/10.1080/15348458.2017.1359608

Bessarab, A., Mitchuk, O., Baranetska, A., Kodatska N., Kvasnytsia, O., \& Mykytiv, G. (2021). Social networks as a phenomenon of the information society. Journal of Optimization in Industrial Engineering, 14(Special Issue), 17-24. https://doi.org/10.22094/JOIE.2020.677811

Bondar, I., Humenchuk, A., Horban, Y., Honchar, L., \& Koshelieva, O. (2021). Conceptual and innovative approaches of higher education institutions (HEIs) to the model of training a successful specialist formation during a COVID pandemic. Journal of Management Information and Decision Sciences, 24(3), 1-8.

Dizon, G. (2021). Subscription video streaming for informal foreign language learning: Japanese EFL students' practices and perceptions. TESOL Journal, 12(2), e 566. https://doi.org/10.1002/tesj.566

Godwin-Jones, R. (2018). Chasing the butterfly effect: Informal language learning online as a complex system. Language Learning \& Technology, 22(2), 8-27. https://doi.org/10125/44643

Godwin-Jones, R. (2019). Riding the digital wilds: Learner autonomy and informal language learning. Language Learning \& Technology, 23(1), 8-25. https://doi.org/10125/44667 
Gonulal, T. (2019). The use of Instagram as a mobile-assisted language learning tool. Contemporary Educational Technology, 10(3), 309-323. https://doi.org/10.30935/cet.590108

Gumenyuk, T., Kushnarov, V., Bondar, I., Haludzina-Horobets, V., \& Horban, Y. (2021). Transformation of professional training of students in the context of education modernization. Estudios de Economia Aplicada, 39(5) (Ahead of print). Retrieved from https://doi.org/10.25115/eea.v39i5.4779

Huzairin, H., Putrawan, G., E., \& Riadi, B. (2020). Technology and language learning: English as a Foreign Language learners' use of smartphones for online informal learning in Indonesia. Texto Livre Linguagem e Tecnologia, 13(3), 103-120. https://doi.org/10.35699/1983-3652.2020.24657

Ismail, I. S., \& Shafie, N. H. (2019). English informal language learning through social networking sites among Malasian university students. Asian Journal of University Education, 15(3), 211-225.

Jensen, S. H. (2017). Gaming as an English language learning resource among young children in Denmark. CALICO Journal, 34, 1-19. https://doi.org/10.1558/cj.29519

Jurkovič, V. (2018). Online informal learning of English through smartphones in Slovenia. System, 80, 27-37. https://doi.org/10.1016/j.system.2018.10.007

Khaleel, F. L., Wook, T. S. M. T., \& Ashaari, N. S. (2018). Quantifying user experience in using learning gamification website. Journal of Theoretical and Applied Information Technology,96(23), 783-793.

Kiki-Papadakis, K., \& Chaimala, F. (2016). The Embedment of responsible research and innovation aspects in European science curricula. Revista Romaneasca pentru Educatie Multidimensionala, 8(2), 71-87. http://dx.doi.org/10.18662/rrem/2016.0802.06

Lee, J. S. (2020). The role of informal digital learning of English and a high-stakes English test on perceptions of English as an international language. Australasian Journal of Educational Technology, 36(2), 155-168. https://doi.org/10.14742/ajet.5319

Lee, J. S., \& Drajati, N. A. (2019). Affective variables and informal digital learning of English: Keys to willingness to communicate in a second language. Australasian Journal of Educational Technology, 35(5), 168-182. https://doi.org/10.14742/ajet.5177

Lee, J. S., \& Dressman, M. (2017). When IDLE hands make an English workshop: Informal digital learning of English and language proficiency. TESOL Quarterly, 52(2), 435-445. https://doi.org/10.1002/tesq.422

Leong, L.-M., \& Ahmadi, S. M. (2017). An analysis of factors influencing learners' English speaking skills. International Journal of Research in English Education, 2(1), 34-41. https://doi.org/10.18869/acadpub.ijree.2.1.34

Li, T., Zou, D., Weng, X., Wang, M., Xie, H., \& Wang, F. L. (2020) Acceptance and implications of smartphones for informal language learning in foreign study tours. International Journal of Mobile Learning and Organisation, 14(4), 456-477. https://doi.org/10.1504/IJMLO.2020.110783

Mykytiuk, S., Lysytska, O., \& Melnikova, T. (2020). Facebook group as an educational platform for foreign language acquisition. Postmodern Openings, 11(1 Sup1), 131-157. https://doi.org/10.18662/po/11.1sup1/127

Pooley, A. W., Midgley, W., \& Farley, H. (2019). Informal language learning through mobile instant messaging among university students in Korea. International Journal of Mobile and Blended Learning, 11(2), 33-49. https://doi.org/10.4018/IJMBL.2019040103

Poplavskyi, M., Rybinska, Y., \& Ponochovna-Rysak, T. (2020). The specific of Synesthesia in contemporary American and English poetry and its impact on the reader. Cogito, 12(3), 297-315. Retrieved from https://cogito.ucdc.ro/COGITO\%20septembrie\%202020.pdf

Popovych, V., Ragimov, F., Kornienko, V., Ivanova, I., \& Buryk, Z. (2020). Development of social and communicative paradigm of public administration in the field of social networks. International Journal of Data and Network Science, 4(3), 2-10. https://doi.org/10.5267/j.ijdns

Prokopenko, O., Osadchenko, I., Braslavska, O., Malyshevska, I., Pichkur, M., \& Tyshchenko, V. (2020). Competence approach in future specialist skills development. International Journal of Management, 11(4), 645-656. https://doi.org/10.34218/IJM.11.4.2020.062

Purnamasari, A. (2019). Pre-service EFL teachers' perception of using Facebook group for learning. Journal of English Teaching, 5(2), 104-114. https://doi.org/10.33541/jet.v5i2.1064 
Putrawan, G., E., \& Riadi, B. (2020). English as a Foreign Language (EFL) learners' predominant language use for online informal learning activities through smartphones in Indonesian context. Universal Journal of Educational Research, 8(2), 695-699. https://doi.org/10.13189/ujer.2020.080243.

Qadha, A. M., Al-Wasy, B. Q., \& Mahdi, H. S. (2021). Using social networking tools for teaching requests to undergraduate Arab EFL learners: a study of pragmatics. Learning and Teaching in Higher Education:Gulf Perspectives, 17(2), 95-106. https://doi.org/10.1108/LTHE-09-2020-0041

Rababah, I. H. M. (2020). The reality of using modern teaching methods in teaching Arabic for speakers of other languages from teachers' perspective. Journal of Social Sciences, 9(1), 58-94. https://doi.org/10.25255/jss.2020.9.1.58.94

Rahimah, C. W. I. C. W. I. (2018). Social media tools for informal language learning: A comprehensive theoretical framework. Asian Social Science, 14(4), 46-50. https://doi.org/10.5539/ass.v14n4p46

Reaser, J. (2016). Developing sociolinguistic curricula that help teachers meet standards. In: K. Denham \& A. Lobeck (Eds.), Linguistics at school, language awareness in primary and secondary education (pp. 91-105). Cambridge, UK: Cambridge University Press.

Şad, S. N., Özer, N., Yakar, Ü., \& Öztürk, F. (2020). Mobile or hostile? Using smartphones in learning English as a foreign language. Computer Assisted Language Learning, 33(8) (Ahead of print). https://doi.org/10.1080/09588221.2020.1770292

Synorub, H., \& Medynska, O. (2019). Development of information culture of students of humanitarian specialities. Information Technologies and Learning Tools, 72(4), 152-167. https://doi.org/10.33407/itlt.v72i4.2922

Trinder, R. (2017). Informal and deliberate learning with new technologies. ELT Journal, 71(4), 401-412. https://doi.org/10.1093/elt/ccw117

Vazquez-Calvo, B. (2020). Guerrilla fan translation, language learning, and metalinguistic discussion in a Catalan-speaking community of gamers. ReCALL, 33(3), 1-18. https://doi.org/10.1017/S095834402000021X

Wang, J. (2017). Cloud computing technologies in writing class: factors influencing students learning experience. Turkish Online Journal of Distance Education, 18, 197-213. https://doi.org/10.17718/tojde.328954

Yurieva, O., Musiichuk, T., \& Baisan D. (2021). Informal English learning with online digital tools: non-linguist students. Advanced Education, 17, 90-102. https://doi.org/10.20535/2410-8286.223896

Zhernova, A. (2018). Information and communication technologies in higher education: Toward the preparedness of the subjects of education for innovation. Scientific Research in Social and Political Psychology, 33, 172-179. 


\section{Appendices}

\section{Appendix A}

\section{Questionnaire for Students}

\begin{tabular}{|c|c|}
\hline 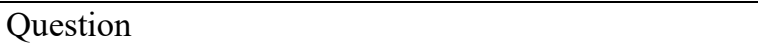 & Answer \\
\hline 1. How often do you use the Internet resources? & \\
\hline $\begin{array}{l}\text { 2. Do you use Web } 2.0 \text { technologies: blog, wiki, } \\
\text { podcast, flickr? }\end{array}$ & \\
\hline $\begin{array}{l}\text { 3. What formats of training Internet resources can be } \\
\text { used at the initial stage of language learning? }\end{array}$ & \\
\hline $\begin{array}{l}\text { 4. What formats of training Internet resources can be } \\
\text { used at the advanced stage of language learning? }\end{array}$ & \\
\hline $\begin{array}{l}\text { 5. What formats would you like to use in the process } \\
\text { of learning a foreign language? }\end{array}$ & \\
\hline $\begin{array}{l}\text { 6. What formats would you like to use in your } \\
\text { professional activity? }\end{array}$ & \\
\hline 7. What formats caused the biggest problems? & \\
\hline $\begin{array}{l}\text { 8. What are the easiest formats to use for learning a } \\
\text { foreign language? }\end{array}$ & \\
\hline $\begin{array}{l}\text { 9. What do you see as the main advantages of } \\
\text { training Internet resources over other training tools? }\end{array}$ & \\
\hline $\begin{array}{l}\text { 10. What disadvantages can you name when working } \\
\text { with training Internet resources? }\end{array}$ & \\
\hline 11. What tasks did you like the most? Why? & \\
\hline 12. What tasks seemed less interesting to you? Why? & \\
\hline 13. What tasks could you suggest? & \\
\hline
\end{tabular}

\section{Appendix B}

\section{Unit 1 Choosing a Career}

Format: Treasure Hunt

Title: Choosing a Career

Technologies Internet 2.0: Blog, Wiki.

Required level of English proficiency: B2

Formed competencies: linguistic, sociolinguistic, sociocultural, social.

Execution time: 90 minutes

Introduction "If you work an 8-hour day from the age of 22 to the age of 62, and never work overtime, you will still spend 400000 hours at your job. That's a long time to be miserable, so it's really important to choose a career that you will enjoy"

Before viewing the websites listed below, print out this page. You will be using this page as a guide for each activity. This page will also be an answer key that must be submitted at the completion of each activity.

Questions

1. Draw a timeline depicting your career interests from kindergarten to the present and into the future, highlighting significant changes. School University

Kindergarten 
2. Study this Mind Map and complete a variety of self-assessments, exploring your personal needs, work preferences (e.g. rural or urban workplace; small or large workplace; structured work time; shift work or flexible time), learning and working styles, salary expectation, motivations and so on.

http://www.kent.ac.uk/careers/Choosing/choosingintro.htm

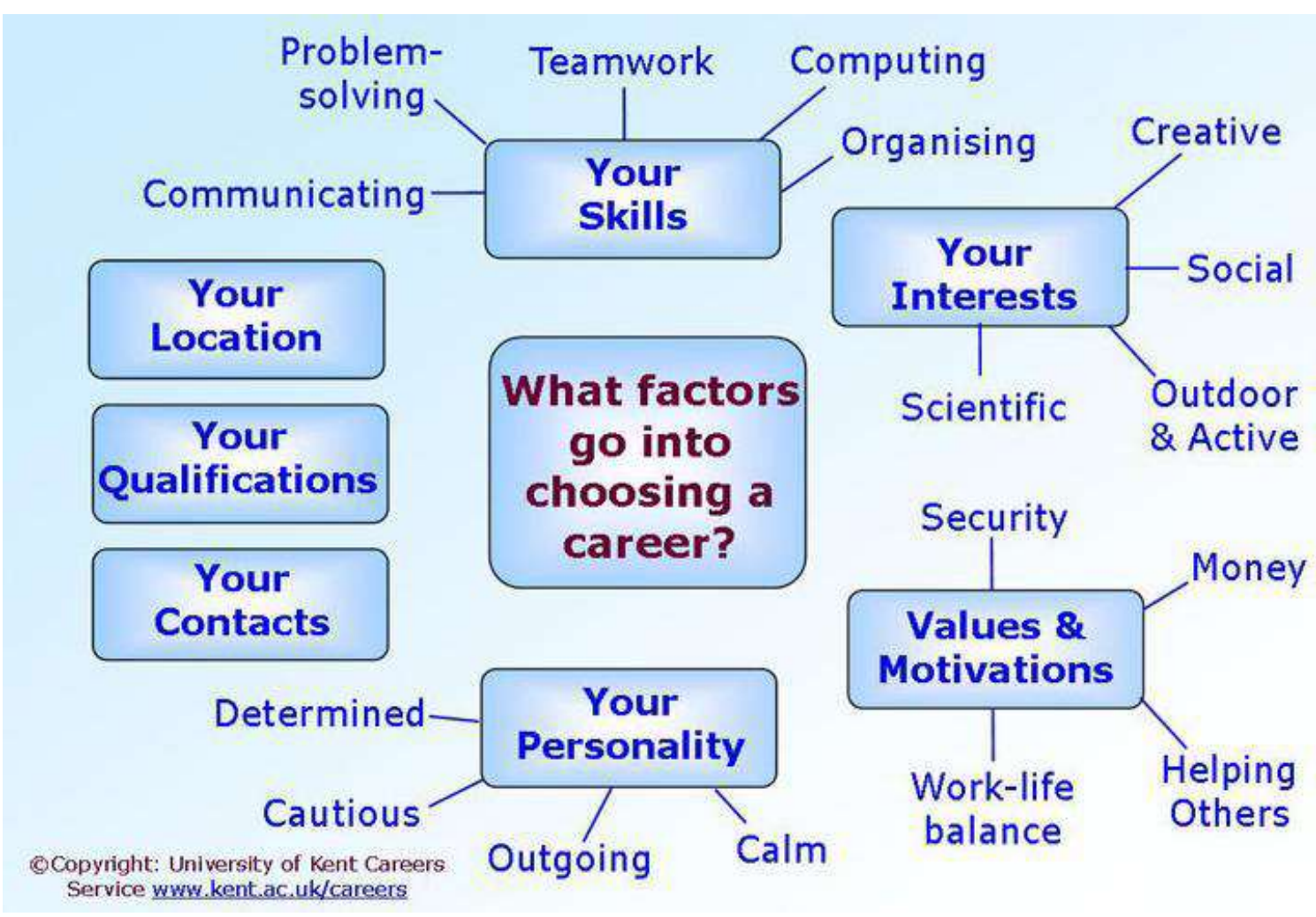

3.Discuss with your partner what does success mean to you? Which of facts are the most/least important?

Wikipedia page http://en.wikipedia.org/wiki/Success

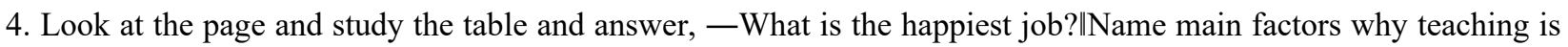
the happiest job. Do you agree with these statements? Why/Why not?

http://www.kent.ac.uk/careers/Choosing/career-satisfaction.htm

5. According to this article what skills are necessary for teaching? Make a list of skills.

http://www.kent.ac.uk/careers/Choosing/career-satisfaction.htm 6. Study the link and fill the table.

http://www.education.gov.uk/get-into-teaching/life-as-a-teacher.aspx

School Year

\begin{tabular}{lcc}
\hline Term & Period & Holiday \\
\hline 1 & & \\
2 & & \\
3 & & \\
Total Days & & \\
\hline
\end{tabular}


The Teaching Week

\begin{tabular}{lll}
\hline Stage & Age Hours
\end{tabular}

Study - Teacher's storyll Paul Keogh's story and fill the chart.

http://www.education.gov.uk/get-into-teaching/life-as-a-teacher/teachers-stories.aspx

Current role

Degree subject

Route into teaching

Interests

How did he find the first job

What does he think about teacher's life

Big Question

Interview your school English teacher and prepare a report about Ukrainian Teaching Timetable, Teaching Week, Teaching Day.

\section{Unit 5 Education}

Format: Hot List

Title: Cambridge

Internet Technologies 2.0: Blog, Wiki, Flicker, YouTube

Required level of English proficiency: B2

Formed competencies: linguistic, sociocultural, social, pragmatic

Execution time: 90 minutes

\section{Introduction}

Looking through the list of earlier Nobel laureates, I note a large number with whom I became acquainted and with whom I interacted during those years as they passed through Cambridge.

John Pope

Task

Study these links and make a full presentation about University of Cambridge and its surroundings for:
a) a historian

or

b) a tourist

or

c) a ESL student

or

d)a sportsman

Links

1. University of Cambridge - official site http://www.cam.ac.uk/

2. History of Cambridge http://www.britainexpress.com/counties/cambridgeshire/az/cambridge/university-history.htm

3. Brief History of Cambridge - wiki page http://www.colc.co.uk/cambridge/cambridge/history.htm 
4. Cambridge and surroundings http://www.visitcambridge.org/

5. Cambridge wiki page http://en.wikipedia.org/wiki/Cambridge

6. Museums of Cambridge lists of museums http://en.wikipedia.org/wiki/Cambridge_museums

7. Museums and Places to Visit - lists of places to visit http://www.colc.co.uk/about/museums.html

8. Cambridge Online Newspaper - news http://www.cambridge-news.co.uk/Home/

9. Cambridge University ESOL Examinations - official site http://www.cambridgeesol.org/index.html

10. Gardens - map http://www.botanic.cam.ac.uk/Botanic/Map.aspx

11. Route map - http://www.stagecoachbus.com/routemaps-cambridge.aspx

12. Walking Tour - http://walkit.com/cities/cambridge/

\section{Appendix C}

Unit 5 Painting

Format: Concept Builder

Title: Renaissance

Web 2.0 Technologies: Blog, Wiki, Flicker, YouTube

Required level of English: B2-C1

Formed competencies: linguistic, pragmatic, discursive.

Execution time: 90 minutes

\section{Introduction}

If every time we encountered something new, we had to learn about it as if we'd never seen anything in our lives before, we'd never get past the bedroom door. Part of learning is being able to group examples of things into sets or concepts that share common elements, or critical attributes. So we know most four-legged fuzzy things that bark are dogs, most Hollywood movies end happily. When you have to tell examples of a concept from those things that aren't, it helps to analyze a group of good examples to see what they have in common. That's what we'll be doing in this activity. If you want to get a feel for what good conceptual learning looks like, review the evaluation rubric that goes with this activity. Either way, get ready to switch on your brain, open your eyes, and begin to recognize the critical attributes that define the key aspects of school safety.

\section{Renaissance}

Use the links below to look at the Renaissance period. Use these examples to find important things that are common traits. Taking all the links together, what are the key features that any example of this concept has to have? Write down the 5 - 10 things you think examples of this concept have to have.

\section{Historical Period}

1. Wiki page http://en.wikipedia.org/wiki/Renaissance

2. European History: Renaissance http://europeanhistory.boisestate.edu/latemiddleages/renaissance/historyren.shtml

3. WebMuseum http://www.ibiblio.org/wm/paint/glo/renaissance/

4. Blog about Renaissance http://www.italian-renaissance-art.com/Italian-Renaissance-Art-blog.html

5. Podcast about art History http://www.learnoutloud.com/Catalog/Arts-and-Entertainment/Painting_-Architecture_-and-Sculpture/Art-History-P odcast $/ 24148$

Art Use the links below to look at examples of Renaissance Art. Try to find important things that are common traits to each example. Taking all the links together, what are the key features of art? Write down the $10-15$ things you think examples of this concept have to have.

1. Wikipage http://en.wikipedia.org/wiki/Renaissance_art

2. Examples and descriptions http://www.students.sbc.edu/kitchin04/artandexpression/renaissance\%20art.html

3. Examples and descriptions http://www.writedesignonline.com/history-culture/renaissance.htm 
4. Photo examples http://www.flickr.com/groups/42758879@N00/pool/with/7982878354/\#photo_7982878354

5. Blog Renaissance Artists http://renaissanceandart.blogspot.com/

\section{Copyrights}

Copyright for this article is retained by the author(s), with first publication rights granted to the journal.

This is an open-access article distributed under the terms and conditions of the Creative Commons Attribution license (http://creativecommons.org/licenses/by/4.0/). 